\title{
ASSESSMENT OF SPECTRAL ANALYSIS OF HEART RATE VARIABILITY IN PATIENTS WITH HISTORY OF ATRIAL FIBRILLATION BY MEANS OF AGE-DEPENDENT PARAMETERS
}

\author{
Jan Galuszka ${ }^{\text {a }}$ Pavel Stejskal ${ }^{\text {, Jan Lukl }}{ }^{\text {a }}$, Jana Zapletalovác
}

\author{
a $1^{\text {st }}$ Department of Internal Medicine, \\ c Department of Biometrics, the Faculty of Medicine, \\ $b$ The Faculty of Physical Culture, Palacký University, Olomouc, Czech Republic, \\ e-mail: jan.galuszka@fnol.cz
}

Received: October 2, 2002

Key words: $\quad$ Atrial fibrillation / Autonomous nervous system / Spectral analysis / Heart rate variability / Ortho-clinostatic test / Age-adjusted parameters

Heart rate variability evaluation is a useful diagnostic tool for autonomic nervous balance assessment. The role of the autonomic nervous system in aetiology of atrial fibrillation is sometimes clear as a trigger from a patient's history, but mostly it acts as a modulating factor which is not easy to detect. The present study demonstrates results of spectral analysis of short-term heart rate variability during ortho-clinostatic tests processed by means of agedependent parameters. An original telemetric system and a unique method for heart rate variability assessment, developed by the Faculty of Physical Culture, were applied for the first time to examine patients with the history of atrial fibrillation.

\section{INTRODUCTION}

Atrial fibrillation (AF) has been underestimated for a long time as a cardiac arrhythmia with enormous consequences for the whole population, especially in industrialized countries. At present, it is generally accepted that atrial fibrillation impairs mortality ${ }^{1}$. Its prevalence is increasing with ageing ${ }^{2}$, and it represents an undeniable economic burden for health care systems $\mathrm{s}^{3,4,5}$. The contemporary level of knowledge on AF is able to recognize several risk factors associated with its development and describe mechanisms of its triggering and spread. The autonomous nervous system (ANS) is a commonly accepted factor participating in arrhythmogenesis., ${ }^{6,8}$ The examination of heart rate variability (HRV) is a noninvasive tool for autonomous nervous system assessment ${ }^{9}$. The measurements of heart rate variability enable analyses in both the time and frequency domain. It is possible to distinguish between three main spectral components via spectral analysis (SA) of the frequency domain, i.e. very low frequency VLF (10-50 mHz), low frequency LF (50-150 mHz), and high frequency HF $(150-400 \mathrm{mHz})$. The high frequency component reflects an efferent parasympathetic activity, the low frequency component is considered as reflecting sympathetic and parasympathetic interactions as well as baroreceptor sympathetic activity. Interpretation of very low frequency is not unambiguous ${ }^{9,10}$. The majority of studies targetting to cardiac autonomous nervous system evaluation in patients with atrial fibrilla- tion describe autonomic tone changes before initiation ${ }^{11}$ or after termination ${ }^{12}$ of atrial fibrillation paroxysms. In this study the authors examined patients with the history of atrial fibrillation by means of a new methodology of heart rate variability evaluation, previously not used in this indication.

\section{METHODS}

\section{Subjects}

Thirty persons (20 men, 10 women) admitted to hospital because of atrial fibrillation, with the left atrium diameter within the abnormal range according to Gregor ${ }^{13}$, were examined after sinus rhythm restoration (spontaneously in $17 \%$, electrically in $20 \%$, pharmacologically in 63\%). The group of patients was characterized by average values of BMI $28 \mathrm{~kg} / \mathrm{m}^{2}$, TSH $2.46 \mathrm{mIU} / 1$, left atrium 39 mm, NYHA I 63\%, NYHA II 37\%. No cause of arrhythmia initiation was detected in $30 \%$ of the patients. In the remainder part of the group an acute trigger factor was revealed in $13 \%$, and there was one or several risk factors, namely hypertension, structural heart disease and diabetes mellitus in $47 \%, 37 \%$, an $13 \%$ of the patients, respectively.

The results of HRV spectral analysis of healthy persons in supine and upright positions published by Šlachta et al. ${ }^{14}$ were used as a control. The control group consisted of 216 healthy persons 12 to 70 years old $(x=35.05 \pm 14.30$ years $)$, where the age dependence of 
single spectral analysis of $\mathrm{HRV}$ parameters was assessed. The results of 30 persons (19 men, 11 women) belonging to this group were selected to ensure the age and gender compatibility with the patients.

\section{Data collection}

The patients were examined between 8 and 11 a.m., eupnoic, at a room temperature ranging from 22 to 25 degrees $\mathrm{C}$, according to standard conditions having abstained from cigarettes, alcohol, and coffee before the examination. Drugs potentially influencing HRV were stopped in half of the patients. In the cases where therapy could not be interrupted, the last dose was administered one day before the examination. Out of the total number of the patients Digoxin therapy was used in $10 \%$, Propafenon in $30 \%$, betablocker in $17 \%$, angiotensin converting enzyme inhibitors in $33 \%$, and Sotalol in $3 \%$.

The original diagnostic systems VARIA PULSE TF $3^{15}$ and VARIA CARDIO TF4 ${ }^{16}$ were used for recording R-R intervals as well as for a short-term (5-minute-duration and $300 \mathrm{R}-\mathrm{R}$ intervals at least) HRV analysis. The test with ortho-clinostatic stimulation (5-minuteduration in each of the supine-standing-supine positions) was performed. The first position served for standardization, and the next two positions with their specific indexes served for alternating sympathetic and vagal stimulation. Incidentally recorded artifacts were removed by manual filtration.

\section{Evaluation of SA HRV}

All the commonly used parameters of HRV spectral analysis were included in the evaluation, namely total spectral power TOT.PWR (ms ), spectral power in individual frequency bands PWRVLF, PWRLF and PWRHF $\left(\mathrm{ms}^{2}\right)$, relative spectral power in individual frequency bands REL.PWRVLF, REL.PWRLF, REL.PWRHF $(\%)$, and the ratio of spectral performances $\mathrm{LF} / \mathrm{HF}$ RAT.LF/HF.

In addition to these parameters, the coefficients of variation were used ${ }^{17}$ in the respective frequency bands CCVVLF, CCVLF, CCVHF (\%) to reduce different effects of heart frequencies on the power field SA HRV. All the measured and calculated values of age-dependent parameters were correlated to reference values of healthy persons ${ }^{18}$ and expressed as points on a -5.0 to +5.0 score scale $^{19}$. It allowed for SA HRV to take advantage of a new original assessment method using complex indexes of vagal activity (VA), sympathovagal balance (SVB), baroreceptors activity (BR) and total score $(\mathrm{TS})^{19}$. TS values were converted to the functional age of ANS for easier interpretation ${ }^{19}$. As compared to the standard parameters, the new method enables easier orientation, easier interpretation of the results and undeniable identification of less pronounced changes in the power spectrum.

The functional age of 71 years was allocated to the patients with significantly low total spectral power, when the computer program was not able to calculate the functional age because of the extended age range of the control group (up to 70 years). This step enabled to measure objective differences, and thus the statistical evaluation was affected to a minimum extent.

\section{RESULTS}

There was a significant decline in the total spectral performance as well as in all the three individual components in supine positions between the group of patients and the control as shown in Table 1.

Table 1. Statistical significance of differences between values of SA HRV parameters and complex indexes during ortho-clinostatic test in patients and healthy control.

\begin{tabular}{|c|c|c|c|c|}
\hline & & Patients & Control & SSD \\
\hline \multirow[t]{2}{*}{ CA (years) } & $\mathrm{X}$ & 54.86 & 50.33 & NS \\
\hline & $\mathrm{SD}$ & 10.62 & 8.25 & \\
\hline \multirow[t]{2}{*}{ L TOT.PWR $\left(\mathrm{ms}^{2}\right)$} & $\mathrm{X}$ & 585.7 & 1873.5 & $\mathrm{p}<0.001$ \\
\hline & $\mathrm{SD}$ & 481.5 & 1368.2 & \\
\hline \multirow[t]{2}{*}{ L CCV VLF (\%) } & $\mathrm{X}$ & 1.17 & 1.81 & $\mathrm{p}<0.01$ \\
\hline & SD & 0.68 & 0.83 & \\
\hline \multirow[t]{2}{*}{ L CCV LF (\%) } & $\mathrm{X}$ & 1.35 & 2.48 & $\mathrm{p}<0.001$ \\
\hline & SD & 0.81 & 1.16 & \\
\hline \multirow[t]{2}{*}{ L CCV HF (\%) } & $\mathrm{X}$ & 1.41 & 2.4 & $\mathrm{p}<0.001$ \\
\hline & SD & 0.77 & 0.99 & \\
\hline \multirow[t]{2}{*}{$\operatorname{L~VLF~(\% )~}$} & $\mathrm{X}$ & 29.3 & 22.6 & NS \\
\hline & SD & 18.8 & 14.5 & \\
\hline \multirow[t]{2}{*}{$\operatorname{L~LF~}(\%)$} & $\mathrm{X}$ & 32.1 & 40.2 & NS \\
\hline & SD & 18.2 & 17.2 & \\
\hline \multirow[t]{2}{*}{ L HF (\%) } & $\mathrm{X}$ & 38.6 & 37.2 & NS \\
\hline & SD & 21.4 & 16.3 & \\
\hline \multirow[t]{2}{*}{$\mathrm{L} \mathrm{LF} / \mathrm{HF}$} & $\mathrm{X}$ & 1.39 & 1.40 & NS \\
\hline & SD & 1.49 & 1.02 & \\
\hline \multirow[t]{2}{*}{ VA (points) } & $\mathrm{X}$ & -1.997 & 0.537 & $\mathrm{p}<0.001$ \\
\hline & SD & 1.8128 & 1.88 & \\
\hline \multirow[t]{2}{*}{ SVB (points) } & $\mathrm{X}$ & -0.408 & -0.353 & NS \\
\hline & SD & 2.3552 & 1.6183 & \\
\hline \multirow[t]{2}{*}{ BR (points) } & $\mathrm{X}$ & 0.297 & 0.395 & NS \\
\hline & $\mathrm{SD}$ & 2.2022 & 2.3883 & \\
\hline \multirow[t]{2}{*}{ TS (points) } & $\mathrm{X}$ & -2.483 & 0.158 & $\mathrm{p}<0.001$ \\
\hline & SD & 2.2742 & 1.7213 & \\
\hline \multirow[t]{2}{*}{ FA (years) } & $\mathrm{X}$ & 62.04 & 49.07 & $\mathrm{p}<0.001$ \\
\hline & SD & 11.36 & 11.01 & \\
\hline \multirow[t]{2}{*}{ CA - FA (years) } & $\mathrm{X}$ & 7.178 & -1.258 & $\mathrm{p}<0,001$ \\
\hline & SD & 8.67 & 5.41 & \\
\hline
\end{tabular}

Explanatory notes: $\mathrm{CA}$ - calendar age, $\mathrm{L}-$ second supine position, $\mathrm{CCV}$ coefficient of variation of the individual component, TOT.PWR total spectral power, VA - complex index of vagal activity, SVB complex index of sympathovagal balance, BR- baroreceptor activity, TS - total score, FA - functional age of ANS, SSD statistical significance of differences between patient and control values

On the contrary, there was no significant difference in power participation of the respective spectral component in total power and LF/HF ratio between the patients and the healthy control. The complex index of vagal acivity (VA) was significantly lower in the group of patients than in the healthy control. However, there were no significant differences between SVB and BR values (Table 1). The total ANS efficiency expressed as 


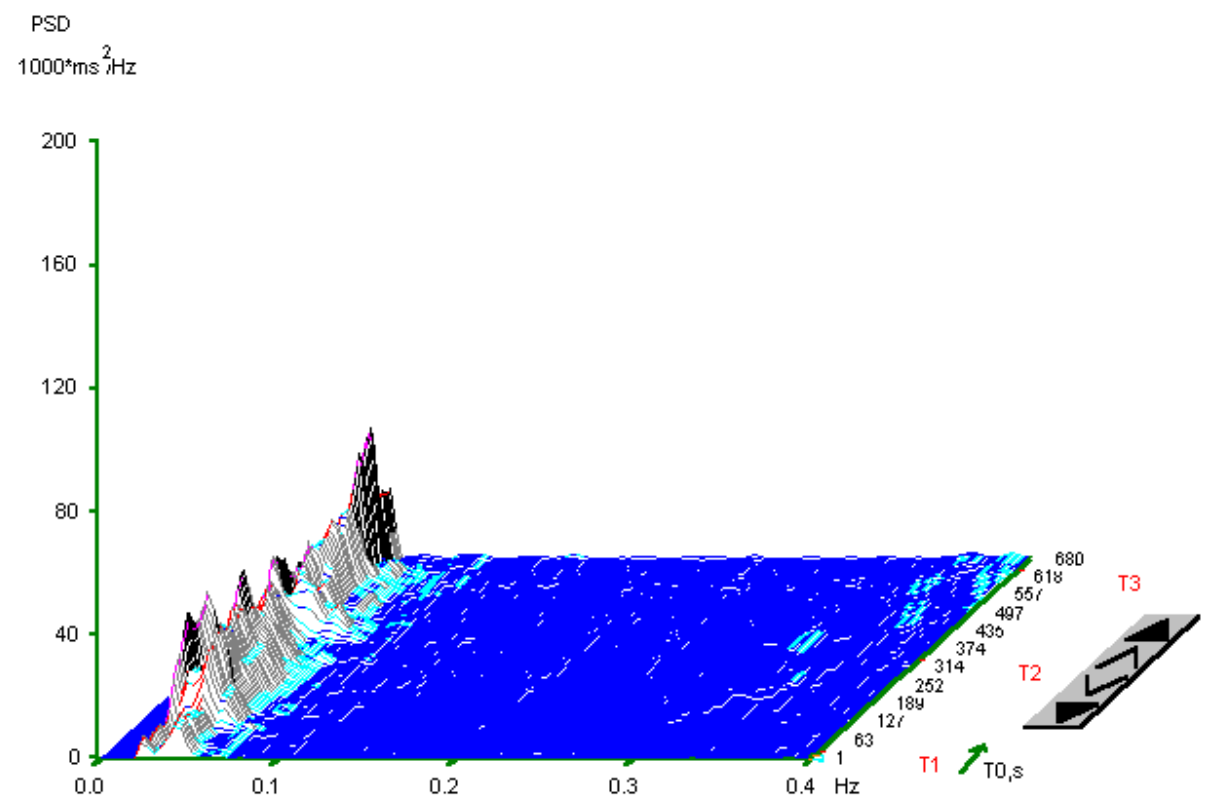

Fig. 1. SA HRV in a 3D graph: a 45-year-old man with history of AF, functional ANS age 55 years.

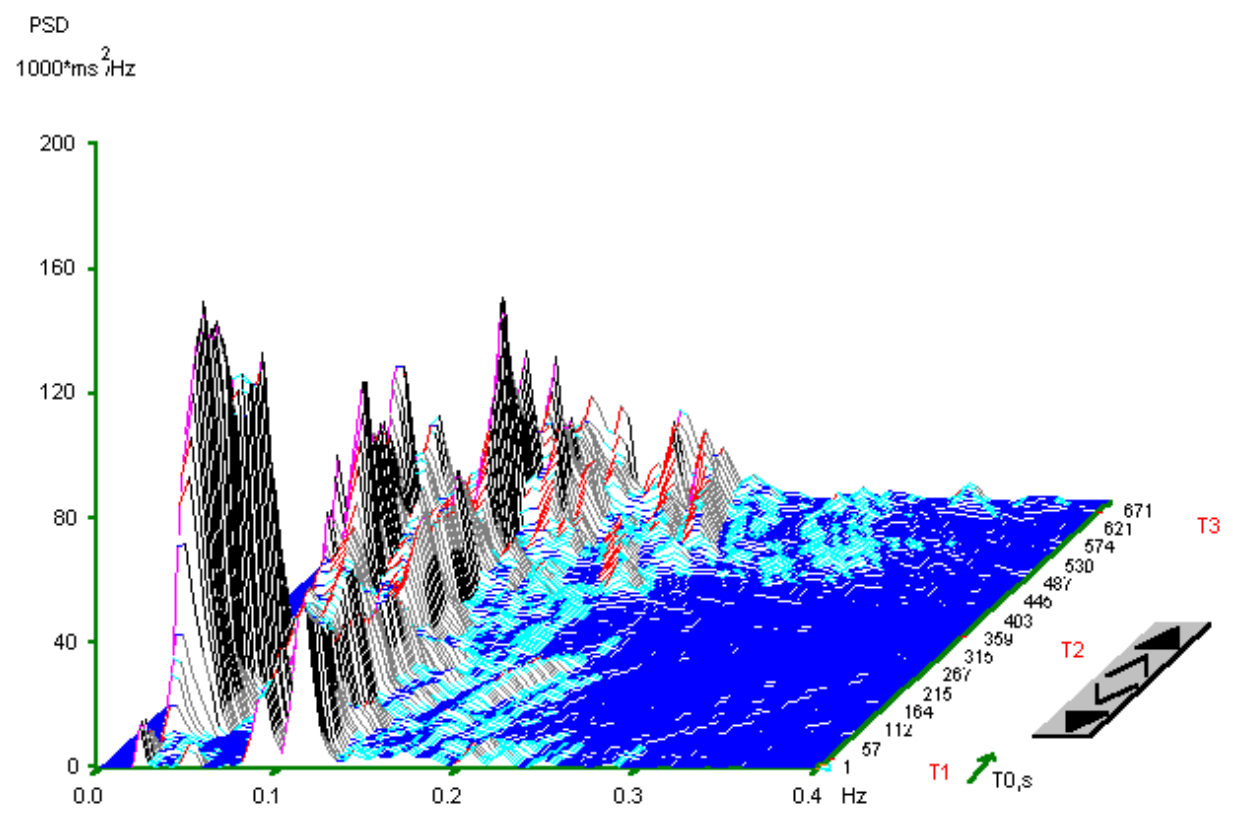

Fig. 2. SA HRV in a 3D graph: a healthy man aged 46 years from the control group, functional ANS age 41 years.

the total score was significantly lower in the group of patients, corresponding with a remarkably higher functional age. The difference between the calendar and functional age was approaching zero $(-1.26 \pm 5.41)$ in the group of healthy persons, but it was significantly higher in the group of patients $(7.18 \pm 8.67)$ (Table 1.).

\section{DISCUSSION}

A significantly depressed vagal activity recorded in the patients with atrial fibrillation history not only reduced the total spectral performance, primarily dependent on vagal fluctuations, but it also remarkably limited the values of the complex vagal activity index VA. This finding is not very surprising, and it is related to the 
depressed vagal activity in many other diseases, e.g. diabetes mellitus. The reduced vagal activity is a major reason for HRV decline as well as ANS efficiency reduction.

On the other hand, it was astonishing to find the sympathetic activity unchanged resulting from $\mathrm{LF} / \mathrm{HF}$ ratio frequently used as a sympathetic tone index. It was identical in the groups of healthy persons and patients. The well-balanced values of the complex sympathovagal balance index SVB approaching zero in both the groups under study confirmed a parallel reduction in both vagal and sympathetic activities. Most diseases are accompanied by sympathetic predominance due to the reduced vagal activity characterized by an increasing $\mathrm{LF} /$ $\mathrm{HF}$ ratio, e.g. chronic heart failure ${ }^{9}$. It is fairly possible to detect a significant decline in SVB index by means of complex indices which gives evidence on the reduction in the overall ANS efficiency, and not only isolated dysfunction of one ANS branch. This finding is also related to a significant difference in the total score of TS values between the group of patients and the healthy control. In the patient group, the ANS activity was significantly beyond the normal range which signalized that ANS dystonia was still outlasting after an attack of the above mentioned arrhythmia.

Quantitative expression of the functional ANS dysfunction by means of the functional age versus the calendar age promoted the first of clear patient-oriented interpretations of the results. However, it has to be taken into account that it brought no further information, thus being redundant in view of the description of SA HRV results.

The activity of baroreceptors assessed as absolute and relative differences in LF component performances after orthostatic stimulation was identical in both the groups under consideration. It is in a good agreement with the fact that the baroreceptor arc is not affected in patients with atrial fibrillation, the cause being an isolated injury of the cardiac neural network peripheral part.

It has been documented that the total spectral performance is declining with ageing ${ }^{20}$. The functional age index is a parameter that could distinguish between the two groups under study at the statistically significant level. This justifies the capacity of the methodology used in our study to differentiate the findings of the patients with autonomous regulation dysfunction from healthy persons. Patient results were classified at the level of significance as age inappropriate, and disadvantageous for them, in accordance with the generally low average of spectral performances.

\section{STUDY LIMITATIONS}

The processed records of the control group were obtained in a different laboratory because it was not possible to make up a relevant group of healthy persons in a clinical setting. Different modes of verticalization were used in both the groups under study, namely active in the patients and passive in the control, Nevertheless, abnormal findings were not probably due to supplementary effort resulting from active standing.

Half of the patients were examined under therapy possibly affecting HRV. The classification of these persons within the study group was based on literature references concerning the impact of drug therapy on ANS. Sotalol, Propafenon, Digoxin, and betablockers were reported to have a supportive effect on vagal activity, incidentally HRV. A favourable and/or neutral effect was found in angiotenzin-converting enzyme inhibitors ${ }^{21,22}$. A major problem revealed in the patient group was attenuation of vagal activity. It is therefore possible to assume that the unfavourable results were not impaired by therapy, but most probably an opposite effect could be expected. There was another limitation, namely the fact that the interval between termination of atrial fibrillation and HRV examination was not defined. The arrhythmia was terminated in early hours after admission to hospital. Consequently, it may be supposed that atrial electrical remodellation was not present when the examination was performed in a stable state on sinus rhythm after time delay in days or longer. The basic pre-requisite for inclusion in the study was a limitation in the atrial diameter, and its normal range demonstrated that anatomical remodellation was not present.

\section{CONCLUSIONS}

1. An ortho-clinostatic test enabled the assessment of cardiac ANS regulation dynamics.

2. There were statistically significant differences among numerous parameters discovered in the patient group via HRV analysis. The basic finding in the group of patients was a low total spectral performance. The most striking differences between the patients and the healthy control were due to the insufficient vagal activity.

3. Based on the fact that a postural maneuvre was found an efficient tool for ANS screening integrity, there might be a cardiac autonomous regulation disorder in the group of patients. 
4. The applied program offers quick orientation in the analyzed data and is able to differentiate healthy persons from patients with pathological findings. The results found in the patients were inappropriate for their age group. The findings were classified as disadvantageous, because the functional age of the patients was significantly higher in comparison with the control group.

5. It may be alleged that the results have confirmed a significantly higher presence of a cardiac ANS regulatory mechanism disorder in the group of patients with the history of atrial fibrillation as compared to the healthy control. Nevertheless, these findings cannot solve the problem of abnormal ANS reaction aetiology. They only show the coincidence with AF which could be considered a proof supporting the presence of ANS dysfunction as a modulating factor participating in AF origin.

\section{ACKNOWLEDGEMENTS}

The authors wish to thank Mgr. Jarmila Potomkova for her assisstance with manuscript preparation, Prof. Jiř́ Salinger for his consultation, and to Mr. Leo Rec for his graphic aid.

\section{REFERENCES}

1. Benjamin EJ., et al. (1998) Impact of atrial fibrillation on the risk of death: The Framingham Heart study. Circulation 98, 946-952.

2 Domanski MJ (1995) The epidemiology of atrial fibrillation. Coron Artery Dis 6, 95-96.

3. Geraets DR, Kienzle MG (1993) Atrial fibrillation and atrial flutter. Clin Pharm. 12, 721-735.

4. Aliot E, Camm AJ, Hohnloser S, Singh BN (1998) Atrial Fibrillation Compendium. London: Current Medical Literature, 1998.

5. Stewart S et al. (2001) Trends in atrial fibrillation-related admissions and case fatality in Scotland, 1986-1995. Eur Heart J 22, Abstract Suppl., 15.

6. Bigger JT, Günter B, Brown AM, Camm AJ et al. (1991) The Sicilian gambit. A new approach to the classification of antiarrhythmic drugs based on their actions on arrhythmogenic mechanisms. Task Force of the Working Group on Arrhythmias of the European Society of Cardiology. Circulation 84, 1831-1851.

7. Fuster V, Rydén LE, Asinger RW et al. (2001) ACC/AHA/ESC guidelines for the management of patients with atrial fibrillation: a report of the American College of Cardiology/American Heart
Association Task force on Practice Guidelines and the European Society of Cardiology Committee for Practice Guidelines and Policy Conferences (Committee to Develop Guidelines for the Management of Patients With Atrial Fibrillation). Eur Heart J 22, 1852-1923.

8. Lévy MN. Autonomic nervous system in atrial flutter and fibrillation. In: Saoudi A, Schoels W, El-Sherif N. Atrial Flutter and Fibrillation. From Basic to Clinical. Armonk, NY: Futura Publishing, 1989. p. 69-85.

9. Bigger JT, Breithardt G, Camm AJ, Cerutti S et al. (1996) Task Force of the European Society of Cardiology and the North American Society of Pacing and Electrophysiology. Heart rate variability. Standards of measurement, physiological interpretation, and clinicaluUse. Circulation 93, 1043-65.

10. Stejskal P, Salinger J (1996) Spektrální analýza variability srdeční frekvence. Základy metodiky a literární přehled o jejím klinickém využití. Medicina Sport Bohem\& Slov 5(2), 33-42 (in Czech).

11. Huang JL, Wen ZCH, Lee WL, Chang MS, Chen SA (1998) Changes of autonomic tone before the onset of paroxysmal atrial fibrillation. Int J Cardiol 66, 275-283.

12. Lombardi F, Colombo A, Basilico B, Ravaglia R et al. (2001) Heart rate variability and early recurrence of atrial fibrillation after electrical cardioversion. J Am Coll Cardiol 37(1), 157-162.

13. Gregor P, Widimský P, Niederle P (1984) Echokardiografie, 2. přeprac. vyd. Praha: Avicenum, 1984.

14. Šlachta R et al. (2000) Application of age-standarded parameters in the evaluation of SA HRV in clinical practice. Acta Univ Palacki Olomuc Gymnica 30(1), 41-48.

15. Salinger J, Vychodil R, Novotný J et al. Telemetric, computeraided system for non-invasive examination of heart rate variability, type Varia Pulse TF3. In: Murray A, Arzbaecher R. editors. Computers in Cardiology. Los Alamitos: The Institute of Electrical and Electronics Engineers, Computer Society Press, 1995. p. 437-440.

16. Salinger J, Pumprla J, Vychodil R et al. Microcomputer system for telemetric assessment of short term heart rate variability in time and frequency domain, type VariaCardio TF4. In: Murray A, Swiriyn S, editors. Computers in Cardiology. Los Alamitos: The Institute of Electrical and Electronics Engineers, Computer Society Press 1999. p. 599-602.

17. Hayano J, Sakakibara Y, Yamada A et al. (1991) Accuracy of assessment of cardiac vagal tone by heart rate variability in normal subject. Am J Cardiol 67, 199-204.

18. Šlachta R, Stejskal P, Elfmark M et al. ( 2002) Age and heart rate variability. Acta Univ Palacki Olomuc, Gymnica 32 (1), 59-67.

19. Stejskal P, Šlachta R, Elfmark M et al. (2002) New methods of evaluation of spectral analysis of heart rate variability. Acta Univ Palacki Olomuc, Gymnica 32(2), (in press).

20. Šlachta R. (1999). Sledování závislosti hodnoty ukazatelů spektrální analýzy variability srdeční frekvence na věku vyšetřovaných osob. Disertační práce. Fakulta tělesné kultury Palackého univerzity, Olomouc (Thesis, in Czech).

21. Lü Fei. (1995) Effects of pharmacological interventions on heart rate variability. In: Malik M, Camm AJ et al. Heart Rate Variability. Armnonk, NY: Futura Publishing 1995. p. 275-285.

22. Watanabe AM (1985) Digitalis and autonomic nervous system. J Am Coll Cardiol 5, 35A-41A. 